Article

\title{
Political Leadership in Parliament: The Role of Select Committee Chairs in the UK House of Commons
}

\author{
Alexandra Kelso \\ Department of Politics and International Relations, University of Southampton, Southampton, SO17 1BJ, UK; \\ E-Mail: a.kelso@soton.ac.uk
}

Submitted: 29 January 2016 | Accepted: 26 April 2016 | Published: 23 June 2016

\begin{abstract}
Concepts of political leadership have been applied sparingly to parliaments, and not at all to the study of House of Commons select committees in the UK Parliament, where analysis has largely focused on their institutional capacity to scrutinise government and hold it to account. Yet examining these committees through a political leadership lens illuminates the complex role of committee chairs, a role which was significantly reshaped in 2010 with a shift to election of chairs by the whole House. This article analyses select committee chairs through the lens of political leadership, and draws on a series of interviews with chairs in order to delineate the nature of the political leadership they perform. It argues that, as chairs are now increasingly important parliamentary and policy actors, our understanding of them is significantly advanced by conceptualising their role as one of parliamentary political leadership, and that this in turn enriches our analytical toolkit when it comes to the study of parliaments.
\end{abstract}

\section{Keywords}

House of Commons select committees; political leadership; select committee chairs; UK Parliament

\section{Issue}

This article is part of the issue "New Approaches to Political Leadership", edited by Mark Bennister (Canterbury Christ Church University, UK).

(C) 2016 by the author; licensee Cogitatio (Lisbon, Portugal). This article is licensed under a Creative Commons Attribution 4.0 International License (CC BY).

\section{Introduction}

Political leadership analysis affords valuable insights into the key actors who have changed the trajectories of contemporary societies, and studies of US presidents and prime ministers in Westminster systems constitute particularly fertile fields for scholars to plough (for a sample see: Bennister, 2012; Blick \& Jones, 2014; Foley, 2000; Greenstein, 1988, 2009; Heffernan, 2005; Hennessy, 2000; McKay, 2014; Neustadt, 1960, 1980; Weller, 2014). Parliament, by contrast, appears to offer a less compelling area of study from a leadership perspective, because, in party-dominated Westminster style systems, the dynamics and interactions that determine parliamentary outcomes are rarely easily distilled into explanations focused exclusively around individuals. However, leadership as a political function is not confined to executive politics, and is necessarily dispersed in any system of democratic governance, yet parliamentary analyses of political leadership are in relatively short supply. While the definitive guide to the topic, The Oxford Handbook of Political Leadership (Rhodes \& 't Hart, 2014a), includes four chapters on prime ministerial leadership, and six on forms of 'political leadership at work', it offers no perspective on parliamentary political leadership. Although leadership analyses have been applied to the arena of legislative politics (for a review, see Norton, 2012), and many studies have been conducted on US legislative leadership (e.g. Caro, 2002; Cooper \& Brady, 1981; Herrnson, 1998; Jewell \& Whicker, 1994; Peabody, 1976, 1985; Peters, 1990; Smith, 2007; Smith \& Deering, 1984; Strahan, 2007, 2011), the UK parliament has not been subject to any such exploration. Consequently, this article poses the following question: can concepts of political leadership be usefully applied to the analysis of the UK Parliament? 
Recent institutional developments at Westminster make this question especially compelling. The House of Commons departmental select committee system has become the key vehicle through which in-depth, nonlegislative executive scrutiny is delivered by MPs. The system's scrutiny capacity has recently expanded, particularly through the role of the committee chairs, who have, since 2010, been directly elected by the whole House, and who thus now possess a range of democratic resources which they did not previously enjoy. As membership of Commons select committees is restricted to backbench MPs, they offer a valuable opportunity to examine whether political leadership is a useful conceptual lens through which to analyse the activities of the chairs who sit at their apex, and thus whether political leadership can be observed in the House of Commons beyond that exercised by the parliamentary party leaderships. This article consequently breaks new ground by analysing the UK Parliament's House of Commons select committees through the lens of political leadership.

The article proceeds in three parts. It begins by exploring relevant insights from the political leadership literature, particularly debates about leadership and followership, and concepts of collaborative leadership. The article then sketches the institutional context in which select committees and their chairs operate, and the implications for a conceptualisation of chairs in terms of political leadership. Finally, the article analyses interview data gathered from select committee chairs between 2011-2012, which explicitly probes the beliefs and understandings of chairs about their role and the extent to which it is one which encompasses leadership. The article advances two key arguments: first, that the political leadership approach is of significant conceptual value for the analysis of House of Commons select committees; and, second, that those who are actually 'doing' leadership can provide us with extraordinarily useful insights into everyday leadership practices, which in turn expands our understanding of what political leadership entails for those charged with performing it.

\section{Political Leadership: Concepts and Themes}

Leadership research seeks to answer two key questions which are central to this article: what is leadership, and how do we know it when we see it? (Rhodes \& 't Hart, $2014 b$, p. 3). If leadership involves someone influencing a group of individuals to achieve a common goal (Northouse, 2010, p. 3), then this raises questions about the method of influence, how common goals are defined, and how consent both constrains and animates leadership across the diverse democratic platforms through which it is exercised, including the parliamentary committee platform which forms the focus of this inquiry. Political and organizational cultures are consequently crucial to understanding the operation and consequences of leadership. Burns (1978, p. 425) defines leadership as 'the reciprocal process of mobilizing, by persons with certain motives and values, various economic, political, and other resources, in a context of competition and conflict, in order to realise goals independently or mutually held by both leaders and followers.' This definition advances understanding in two key ways: first, by qualifying 'leader-centric' accounts which focus largely on the actions of individuals in leadership positions; and second, by drawing into the analysis those whom leaders seek to lead as well as the context in which such leadership occurs. We need to understand not just the motivations of leaders, but the motivations of those who follow, which is highly significant for the questions explored in this article. Political leaders derive their authority not just from the democratic procedural arrangements through which they ascend to the top of organizational structures, but also from the 'processual' mechanisms through which leaders engage in exchange relationships with other actors (Hartley \& Benington, 2011, p. 207), and the degree of trust placed in leaders by followers delimits the bounds of democratic political leadership (Ruscio, 2004), which necessarily springs from consent (Kane \& Patapan, 2012). Two interrelated themes thus frame the parliamentary analysis pursued here: first, the distinctions between and debates about leadership and followership; and, second, the concept of collaborative leadership and the centrality of soft and smart power to its effectiveness.

\subsection{Leadership and Followership}

Contemporary scholarship explores leadership 'as an interactive process between leaders and followers; institutions and the rules of the game; and the broader historical context' (Rhodes \& 't Hart, 2014b, p. 6). Leadership is not simply a matter of 'a leader acting and a group of followers responding in a mechanical way', but is instead a highly complex social process in which the organizational cultural context is fundamental in shaping interactions (Alvesson, 2011, p. 152). It is impossible to understand leaders without understanding those they seek to lead, and the environment in which such leadership occurs, and follower-centric approaches to leadership analysis have largely eschewed individualistic and 'heroic' approaches (Meindl, 1990, 1995). If the term 'followership' is controversial, such controversy is itself emblematic of the need to understand leaders and followers in relation to each other, and to their organizational and social environments. Successful leaders are those who 'succeed in appealing to, embodying or modifying the social identities of their followers' (Rhodes \& 't Hart. 2014b, p. 6). Crucially, as leadership involves 'leaders inducing followers to act for certain goals that represent the values and the 
motivations... of both leaders and followers', the 'genius of leadership' therefore involves drawing actors together 'in pursuit of a common or at least joint purpose' (Burns, 1978, p. 19).

Yet, the terms 'leaders' and 'followers' have different meanings in different contexts, and organizational culture will significantly determine whether actors even acknowledge them as meaningful to their regular interactions. While in some organizations, the leader/follower distinction will be clear and accepted terminology, in others these definitions and their applicability will be open to debate. In particular, the identity, motivations and values of so-called followers will shape leader-follower relations, hence why it is crucial to analyse the 'proverbial 'other side' of the leadership coin' (Bligh, 2011, p. 426). Context will at least in part determine whether actors in a political organization are agreeable to the leader-follower distinction, not least because those who are already members of the political elite may balk at the notion of contexts in which they are defined as followers.

Yet although there is debate about the use of the term 'follower' (Burns, 2005; Rost, 2008), the term is not in itself necessarily derogatory. Baker (2007) demonstrates that both leaders and followers are roles rather than individual characteristics; that followers are active rather than passive; and that leaders and followers share common purposes rather than the former imposing purpose on the latter. Similarly, work on relational leadership theory (Uhl-Bien, 2006), leadership complexity theory (Uhl-Bien, Marion, \& McKelvey, 2007), and distributed leadership (Gronn, 2002) have sought to treat leadership as an interactive dynamic relationship between organizational actors from which adaptive outcomes emerge' and which emphasize the importance of 'interdependence, coordination and...reciprocal influence' (Bligh, 2011, p. 427). Followership research has demonstrated that it has multiple meanings, and that followers construct those meanings not just in relation to their own individual perceptions, but also in relation to their organizational context and to the leaders with whom they interact (Carsten, Uhl-Bein, West, Patera, \& McGregor, 2010). Heifetz, Grashow and Linksy's (2009) analysis of adaptive leadership is particularly useful in understanding group dynamics and the crucial leadership skill of empowering groups to deal with issues and challenges in relation to the group's context, rather than the leader simply dictating action from above ('t Hart, 2014 , p. 105). These insights allow us to conceive of leadership and followership as necessarily imbued with 'multiple, shifting, contradictory and ambiguous identities' (Collinson, 2005, p. 1436) which reflect the dynamics of the organizational terrain in which they operate. Finally, the idea of leadership as a distributed resource which is shared with followers is crucial to understanding its conceptual utility in the specific parliamentary context which forms the analytical focus of this article.

\subsection{Collaborative Leadership and Leadership Resources}

To the extent that modern democratic governance takes place through 'leadership constellations' (Hendriks \& Karsten, 2014, p. 52) and networks of interdependent actors (Rhodes, 1997), and to the extent that the complexity of modern societies compels the rejection of institutionalised hierarchy and the embrace of collaborative governance ('t Hart, 2014, p. 88), then effective political leadership consequently requires negotiation with stakeholders, and the capability to bind stakeholders together through various interaction processes in the pursuit of common endeavours (Klijn, 2014 , p. 404). Goal alignments between leaders and followers arise only through complex interaction processes designed to manage actors' strategic behaviours (Klijn, 2014, p. 406). Iterative collaboration is therefore fundamental for democratic governance (Ansell \& Gash, 2008), and successful political leaders facilitate collaboration between participants through processes of negotiation and, crucially, by securing agreement about the end goals of collaboration. Collaborative leadership thus involves relationship-building between actors who may otherwise have no obvious motivation to work together, and, because leaders must mobilise actors, they must also understand 'other actors' perceptions and desires about the problems and the solutions' which they are tackling (Klijn, 2014, p. 408). These key insights from collaborative leadership approaches are fundamental in framing our analysis of the political leadership that can be observed inside Commons select committees, a point upon which we will expand shortly.

Collaborative leadership approaches sketch the type of political leadership that is likely to be found inside parliamentary committee environments, and consequently also point to the sort of leadership tools that we might observe in use. Here, Nye's (2008) distinctions between 'soft', 'hard' and 'smart' power are useful in mapping the resources that are available to select committee chairs, and the skills they are required to deploy. Soft power involves emotional intelligence in order to manage relationships, strong communication skills across different audiences, and the ability to articulate a vision which is attractive to diverse stakeholders while still advancing group goals. Hard power involves organisational skills and the management of information flows, as well as the more Machiavellian skills of strategic negotiation and bargaining. Smart power involves combining soft and hard power resources, in order to understand how changing institutional environments affect the group, to capitalise on emerging trends, and to adjust leadership style in relation to the needs of followers (Nye, 2008, p. 83). As Blondel (2014, p. 714) notes, smart power also involves leaders being prepared 'to examine the views of others' and 'rethink and assess what is being proposed as 
a result of objections raised'. Smart leadership therefore involves persuasion but also compromise. This is of crucial significance in understanding the extent to which political leadership is a meaningful category in the analysis of parliamentary select committees.

The political leadership literature therefore offers key analytical angles that can help us understand the role, capacity and action of parliamentary committee chairs. These actors have not yet been examined from a political leadership perspective, yet debates about leadership and followership, the dynamics of collaborative leadership, and the soft, hard and smart power resources which are available to leadership actors all provide valuable analytical leverage. The next section explores the House of Commons select committee context in order to demonstrate this analytical utility and the extent to which committee chairs can be considered as political leaders.

\section{House of Commons Select Committees: Political Leadership Context and Contingencies}

In the UK's asymmetrical political system, the resources of the executive significantly outstrip those of parliament and the MPs tasked with holding government to account (Judge, 1993; Norton, 2013). Committee-based infrastructure is designed as a partial remedy to this power asymmetry. It imbues groups of MPs with the capacity to pursue executive scrutiny away from the floor of the chamber in a way that both dampens MPs' partisan instincts and enhances their interrogatory capacity vis-à-vis executive actors. House of Commons departmental select committees shadow government departments, investigate departmental policy, administration and expenditure, and examine the work of associated agencies and public bodies. These committees are largely viewed as making a positive contribution to government scrutiny, albeit with qualifications (e.g. Drewry, 1985; Giddings, 1985, 1994; Hindmoor, Larkin, \& Kennon, 2009; Judge, 1992; Russell \& Benton, 2011). They inquire into policy issues, take evidence from a range of actors and stakeholders including government ministers, and publish recommendations for policy and operational improvement, many of which are adopted by government (Russell \& Benton, 2011). Through their inquiries, select committees provide a public arena, or 'theatre of action' (Uhr \& Wanna, 2000), through which government actors may be interrogated, evidence presented and queried, and arguments articulated regarding the focus and impact of public policy and executive decision making. The Liaison Committee, the committee on which all select committee chairs sit, contributes to this work by taking evidence on a regular basis from the prime minister, which constitutes a significant innovation in parliamentary committee scrutiny (Kelso, Bennister, \& Larkin, in press). Select committees have also become increasingly visible actors in the news media, because committees' cross-party character and in-depth investigatory approaches are perceived to render critical inquiry conclusions relatively authoritative. There are four key points to delineate in terms of the operation and organisation of select committees that together demonstrate the value of the political leadership analytical lens sketched above.

First, the development and evolution of the select committee system since its creation in 1979 has imbued the chair role with the potential for political leadership and parliamentary authority. Organisational reforms have progressively delimited the ability of frontbench party business managers and whips to determine committee memberships and thus constrain capacity for action. In 2001, government backbench MPs refused to authorise the slate of new committee members in protest against what was perceived to be the malign influence of party whips in the membership selection process, which prompted internal party changes to membership nomination procedures (Kelso, $2003,2009 a)$. In 2009, those in favour of a more vigorous select committee system capitalised on the tumult caused by the MPs expenses scandal to successfully secure an overhaul of committee membership processes (Kelso, 2009b; Russell, 2011). Since 2010, select committees have been appointed under rules which involve the entire House of Commons electing MPs to the select committee chairs. MPs run for election for the chair positions available to their party (the number of chairs assigned to parties is in proportion to seat share), and must attract support from across the parties to get onto the ballot. With committee chairs no longer arguably in the gift of the party whips, and with MPs compelled to secure cross-party support in order to be elected to the chair, this development in select committee organization has had clear consequences for the perceived legitimacy of chairs and also for their agency and capacity for action. To the extent that chairs can utilise the political capital derived from their electoral legitimacy for particular political and/or organizational ends, and can use it in a way which advances committee goals and shapes the behaviour of other committee members, then leadership of some form is in evidence. If select committee chairs are imbued with authority and leadership potential because of their direct election by MPs, then the key question is how that potential is actually used. To what extent is the enhanced political capital of chairship being converted into the powerful political currency of leadership?

Second, the operational context in which chairs function demonstrates the necessity of effective leadership. Select committees have formal powers to call witnesses to give evidence, and to request information and documents from relevant stakeholders in order to run their inquiries. They produce inquiry reports which detail what the committee discovered, the conclusions 
it drew, and the recommendations it makes to specific policy actors. These activities require coordination from the chair, but the role extends beyond simple process management. Chairs must secure agreement from members about committee policy agendas, inquiry focus, and report arguments, none of which would otherwise spring organically from a group of MPs from different political parties. The process management of select committee work is only meaningful if the committee has already agreed on its goals. While the generic goal is that of executive scrutiny, the specific goals will vary from inquiry to inquiry, and chairs must be skilled at navigating the competing goals of MPs from different parties in relation to different topics of policy inquiry. This work necessarily involves collaborative political leadership, because the institutional committee context and the nature of committee membership means that chairs cannot adopt command-andcontrol approaches to agenda setting and inquiry goalidentification and expect members to go along with it. Goal alignments (Klijn, 2014) and iterative collaboration (Ansell \& Gash, 2008) amongst members are essential, and both depend on at least a minimal level of relationship-building amongst individuals from different party backgrounds in order to enable participants to understand issues from the perspective of others (Klijn, 2014 , p. 408). This is a function that only committee chairs are institutionally positioned to perform.

Third, while select committees are cross-party, this does not make them non-party. Chairs must navigate the party loyalties and preferences of members in a way that maintains committee consensus while still facilitating the expression of divergent views from members about the need to be critical of government. This is a crucial point, because select committees reflect party seat share, and therefore have an in-build government majority. Although their cross-party membership means that select committees generally focus on the operational detail of policy when they examine divisive matters, the question of whether and how to criticise government policy and decision making will naturally present challenges for committee MPs. Select committee scrutiny of government, and its policies and decision making, can only be maximized if members operate mostly consensually for most of the time. Consequently, MPs on the government side may be hesitant about endorsing strenuous critiques, while opposition MPs may seek just the kind of full-throated savaging that is likely to make the committee majority balk. While a degree of partisan self-constraint amongst members is likely, given the fundamental task of the select committee system, whoever sits in the committee chair must nevertheless ensure that consensual working is achieved amid these competing objectives, because otherwise the purpose of the select committee is defeated. It is in managing the potentially conflicting demands of committee MPs, and in forging agreed goals from a mix of competing individual motivations, that the chair role transcends administrative coordination and becomes a vehicle for collaborative political leadership. Chairs must navigate the partisan instincts of committee MPs, ensure committee minorities are not routinely thwarted, and avoid offending MPs' highly independent and fiercely autonomous sensibilities. Collaborative leadership is clearly essential for generating the consensual outputs which underpin committee contributions to democratic governance, and requires chairs to deploy a mix of soft, hard and smart skills in order to both agree and secure committee goals.

Fourth, and emerging from the previous points, the leader/follower dynamic is highly germane in the select committee context. The committee chair is integral to a select committee 'team' that is 'composed of members who are interdependent, who share common goals, and who must coordinate their activities to accomplish these goals' (Kogler-Hill, 2010, p. 241). The institutional position of select committees as consensual groups embedded in an inherently partisan organizational environment requires the deft navigation of the parameters of followership inside the select committee environment. In fact, the parliamentary arena is a remarkably useful place to probe what followership actually means in the context of democratic collaborative governance amongst elites. Members' party loyalty will largely take precedence over the strategic goals of the committee, and chairs must operate with a situational 'mental model' which is sensitive to the 'contingencies that define the larger context of team action' (Kogler-Hill, 2010, p. 243). If 'organizational cultures provide actors with sets of beliefs about the nature and role of leadership' (Rhodes \& 't Hart, 2014b, p. 6), then effective chairs are those who understand the constraints on, and limits to, a committee's scrutiny capacity as defined both by the specific parliamentary context and the broader political environment in which the committee operates. Organizational culture is paramount, and leadership requires a willingness not only to acknowledge the limitations created by that culture but also to generate adaptive responses to it (Shein, 1992 , p. 2), and to the various motivations of committee members, in order to advance committee goals. Select committee chairs are therefore 'interactive leaders' (Burns, 1978, p. 15). Furthermore, leadership is necessarily distributed and shared, because committee chairs operate in a context in which group members already enjoy an elite status, and in which the crossparty organizational dynamic renders notions of 'followership' difficult to sustain.

To summarise, the increasing importance of select committees and their scrutiny work to effective parliamentary functioning, the institutionally elevated position of committee chairs as a consequence of House of Commons election, and the complexities of committee operation all demonstrate the requirement for in- 
tentional political leadership inside select committees. The tensions inherent in leadership and followership are directly relevant to select committee environments where members are highly autonomous political elites, while the concept of collaborative leadership usefully frames the type of leadership that chairs might pursue in order to secure member support of committee goals. The value of the political leadership perspective is borne out in interviews conducted with select committee chairs, as the next section demonstrates.

\section{Perceptions of Leadership amongst Committee Chairs}

What do chairs themselves think about their committee roles? What are their beliefs and understandings about their work, about their relationships with other committee members, and about the strategies they adopt in order to discharge committee tasks? Do chairs see their role as one of leadership? These questions framed a series of interviews conducted with select committee chairs, during 2011-2012. There were eight interviews in total, which included chairs from all three of the UK parliamentary parties which were assigned chair positions in the 2010 parliament (Conservative (2), Liberal Democrat (2), and Labour (4)), in which the Conservatives and Liberal Democrats ran a coalition government, and Labour was the official opposition party. The findings from the interviews are explored in the context of the key themes of collaborative leadership, leadership and followership, and in the context of the leadership resources deployed by chairs in relation to Nye's (2008) soft, hard and smart power categories.

\subsection{Collaborative Leadership and Committee Practice}

The interview evidence strongly suggests that the concept of collaborative leadership is highly applicable to the select committee context, and recognisable in the actions of chairs. One committee chair perfectly expressed the need for collaborative leadership when she remarked, 'So, you are looking to see how we turn a group of disparate, strong-willed individuals into a pack animal?' (interview, July 6, 2011). Her view was that most 'outsiders' failed to understand this essential metamorphosis which had to happen for committees to work even at a minimal level, and that relationship building amongst members was crucial. This necessarily took time, and did not just 'magically occur' at the start of a new parliament, but she insisted that 'they do start to hunt as a pack, despite the fact that they're from different political perspectives-it does happen.' The extent to which this transformation occurred was due, in her view, in no small part to the leadership capacity and activity of the chair in deliberately 'breaking down that resistance'. In order to do this, a range of leadership resources must be deployed, and it was those of Nye's (2008) soft and smart variety which featured most prominently in chair responses.

For example, this same chair explained that a key step towards achieving this 'breaking down of resistance' involved the committee travelling overseas on a fact-finding trip as part of an inquiry launched early in the new parliament. 'Those who went on that trip', she argued, 'came back as a more coherent group' (interview, July 6, 2011). And not all trips had to be exotic: this chair also noted the utility of UK-based fact-finding trips, and meetings with members of the public away from Westminster, as key to building a 'team ethos' around a policy focus and dampening partisan instincts. In fact, several chairs reported the usefulness of away days and trips out of Westminster for building collegiality amongst committee members who might otherwise regard one another's motivations warily. Being removed from the physical environment of Westminster, with its oppositional politics and oppositional spaces, and traveling and eating together for sustained periods of time, enabled MPs to share their common interests in terms of the policy focus of the committee. Astute committee chairs used these opportunities as key leadership tools to help build the collegiality that was required for their committees to function effectively. These trips may have been organised for instrumental inquiry purposes, but they also enabled chairs to deploy the soft skills required for relationship building.

Clearly, fact-finding trips go only so far, and much rests on the chair's capacity to foster and sustain collegiality in the longer term. One chair explained that, 'one of the skills that a chair needs is an ability to operate in a collegiate manner, because select committee reports are pretty useless if they are divided' (interview, July 4, 2011). He argued that chairs were required to understand 'that there are some political boundaries you will not be able to cross' when it comes to shifting the political positions of both government and opposition MPs on committees, and that chairs had to handle the processes of compromise. These skills were particularly crucial for report drafting, which the interviewees identified as a key moment in the work of a committee. Inquiry reports are the most important outputs generated by committees, and the main vehicle through which they articulate arguments about government policy, decision making, and administration. It is essential that committees produce consensus reports, because split committees with majority and minority reports are entirely at odds with the purpose of the system. Engineering consensus at the point of report drafting, in terms of agreeing the line of argument and the nature of any criticisms dispensed, is therefore crucial. Consequently, chair leadership involved not only the soft skill of accurately identifying when members had reached the boundaries of consensus; it also involved the hard power of bargaining with members in order to identify the optimum compromise 
arrangement which still enabled the production of robust inquiry reports.

On this point, an opposition party chair spoke at length about her role in facilitating compromise through negotiation, noting that it was important for her to spot partisan clashes in advance of committee meetings, and to work out 'what the lines might be as to how far you can push, and who will accept what, in terms of getting the compromise' (interview, July 6, 2011). Crucially, her strategy eschewed dealing with conflict through private meetings:

'I don't want the committee to think that I'm setting up cabals....because if I start to do that, they would start to do that...I'm trying to build a cohesive group of people who will come up with sensible suggestions that government might enact. And if I start playing one off against the other...well, the last thing I would want to do is to undermine that sense of the collective.' (interview, July 6, 2011)

Compromise was instead engineered in full committee where everyone could have their say. For example, one chair explained the need to ensure that any MPs who 'have expressed doubts...have the opportunity to explore those doubts as part of the investigatory process' (interview, July 4, 2011). Particularly notable is that most chairs reported using the skills of the committee clerks to help produce report language that all members could live with. Thus, compromises often involved the use of what one chair described as 'carefully chosen language' to ensure that the final committee reports did not 'simply provoke' controversy (interview, December 4, 2012), but constructively identified key failings in policy, decision making or implementation in a manner that respected the consensual committee style. Chairs consequently lead not by individual heroic efforts in brokering agreements, but by making the entire committee responsible for securing consensus and drawing on all skill sets available to maximise success, including those of committee clerks who typically have far more experience of the practicalities of report drafting than do committee members. Clearly, collaborative and dispersed leadership is in evidence. Thus, although committee chairs are elected, their democratic legitimacy does not allow them to impose solutions on divided committees, precisely because of the followership dynamics mapped earlier. Instead, chairs are compelled to draw on a range of institutional resources, and soft, hard and smart power strategies, in order to secure successful outcomes.

There are additional contingencies, one of which is that challenges associated with committee leadership differ depending on whether the chair is a member of the party of government or opposition. An opposition party chair explained that his role was different to that of a government party chair: 'where it's much easier [for the chair] to carry his own point of view, because he's always got a majority. Again though, he's got to handle dealing with the minority, and making sure that he gets buy-in from there. I've got a slightly different problem, in that the minority are more likely to share my view on a Political-with-a-capital-P issue, but I've got to get buy-in from the majority ...So there are different skills required in trying to maintain the momentum of the team.' (interview, July 4, 2011)

Similarly, while chairs may be highly active when it comes to private committee meetings where inquiry reports are being agreed, their activism may be less noticeable during committee oral evidence sessions. One chair explained that the allocation of questions for such sessions will be determined in advance, and that while his role involved asking the opening set of questions, thereafter he viewed his role as:

'to try to keep us to time, which is sometimes difficult; to keep to the strategy; and when somebody has a smart idea, to make sure they catch my eye and they interject...So once the system is rolling, the most successful session is, in a sense, the one where I am totally quiet, because it's all gone to plan and the right information has come out.' (interview, July 4, 2011)

In this conception of leadership, attention is not primarily focused on the chair at all, at least not during evidence sessions, where the chair acts largely as a facilitator and enabler for other committee members. That does not mean the role is marginal. This chair was clear that 'the one thing you cannot do as chair is busk, and when you go the meetings, you've got to know what's going on' (interview, July 4, 2011). The chair's ability to focus and 'allocate attention purposefully' ('t Hart, 2014, p. 40) is regarded as a key leadership skill (Goleman, 2013), and is thus essential for the committee's strategic success and the delivery of inquiry goals.

\subsection{Defining and Contesting Leadership and Followership in Select Committees}

While this article argues that political leadership is clearly identifiable in the actions and strategies of select committee chairs, a key question posed by the research was whether chairs themselves would describe what they do as leadership. The interviewees expressed differing opinions on this point, which offer compelling insights into the chair role specifically and the contingencies of political leadership generally, but also into the beliefs of actors about whether 'leadership' was an appropriate way to describe what they do. One chair was clear that: 
'It is a leadership role. It's similar to the skipper of any team. You've got to keep people focused on the job in hand, occasionally deal with details that prohibit them [being involved]...and just make sure that all of them have got the opportunity to engage fully.' (interview, July 4, 2011, interviewee's emphasis)

Another chair agreed that 'there is a leadership role' (interviewee's emphasis), and connected this not only to the broad programme of work undertaken by a committee, but also to the chair role in terms of managing the inquiry report-writing process, media relationships, and interactions with external stakeholders, 'where you do lead in those senses' (interview, December 4, 2012). One chair explained his committee chair role in terms of 'providing leadership in the committee, and to be the external face of the committee', emphasising the public visibility that he believed committee members accepted, and in some cases expected, as a fundamental aspect of the role (interview, July 12, 2012). Nye's (2008) soft power of communication is thus a vital part of the chair leadership toolkit: the chair is the public face of the committee, particularly in the news media, and must be able effectively to articulate the arguments made by the committee in inquiry reports.

The election of committee chairs was also identified as a key resource which imbued chairs with leadership potential. For example, one chair agreed that he acted in a leadership capacity, and explained that this capacity 'has got nothing to do with my status, seniority, age or anything else...I have been elected to do the job, I'm paid to do the job...and I give more of my time and my commitment than any other committee member as a consequence' (interview, July 12, 2012).

Yet, elected status was nevertheless contingent. Another seasoned chair reflected that:

'I wouldn't put a label around my neck saying 'I am the leader', because they [the committee members] might feel you need taking down a peg in that case.' (interview, July 14, 2011)

Thus, leadership is not to be brandished, even when one is elected. Yet, this same chair continued:

'But it is a leadership role. And actually committee members do look at you in that way, and expect you to show leadership to them. They will come with different and often conflicting ideas, and as with any leader, although it might not have been my first thought, my sense is that we will go with that if there's enough support and interest. But at other times, you might need to make the committee realise that there's something they've got to do which shouldn't be neglected, and that's a leader- ship role. They [the committee members] also expect you to fight on their behalf.' (interview, July 14, 2011)

One chair gave a particularly insightful description of her chair role, and its dynamic dependence on the rest of the committee membership, when she explained that:

'I'm a leader, but I'm very conscious that I'm in the hands of the committee, and I have to keep their confidence, and have their agreement on what I'm doing, or we would have a very divided committee, and that would damage it's work.' (interview, June 20, 2011)

It may seem obvious enough that leaders can only lead if they have the support of those with whom they work, but the broader partisan political context in which select committees operate makes this especially salient. This same chair gave an example from an inquiry during which she had been highly critical of a government minister, and where 'the committee supported me in that criticism' (interview, June 20, 2011). She reported bringing the committee together for the purpose of securing their agreement in advance of issuing her highly critical comments, precisely because she needed the committee to maintain a position of consensus for her criticism as chair to have any value. As a member of the opposition party, she explained, it was especially important for her to ensure that the governing party MPs on the committee would agree to this course of action. In this instance, as in so many others affecting select committee work, consensus is king, actors are interdependent, and collaborative and adaptive political leadership is key.

One chair from the government side explained that, when he originally sought election to his committee chair, he made it clear to MPs:

'that I wasn't interested in being a chair that simply sat on the side-lines and offered some kind of running commentary. What I wanted to do was to engage the select committee, real time, in the policy making process.' (interview, May 24, 2011)

He believed that direct election had helped him fulfil his more expansive role for the chair, but was nonetheless hesitant about describing himself as a 'leader', offering the word 'catalyst' instead (interview, May 24, 2011). When pressed on why 'leader' was an unsuitable term, he responded that, 'it implies that others are followers, and that's not necessarily how Members of Parliament like to see themselves.' This captures the dilemmas at the heart of the leader-follower debate, and the frequent unease surrounding the applicability of the notion of followership as an essential compo- 
nent of leadership in the world of political elites. And this view was not isolated. Another chair similarly rejected the idea that she was a leader of her committee, saying she 'would rather be the facilitator...than leader' (interview, July 6, 2011). Yet her description of her role mirrored that of another chair who fully accepted the leadership label, even down to the detail of explaining that a good committee chair doing a good job tends not to be noticed by their members during inquiry sessions. Similarly, she argued that the extent to which the chair could 'set the tone' of a committee, and 'encourage everyone to contribute' was the determining factor 'in whether you've got a functioning select committee or a dysfunctional one' (interview, July 6, 2011). The fact that two senior committee chairs could both use such similar language to describe the role and importance of the chair, but then take differing views on whether that role constitutes leadership, reveals much about the nature of interactions inside select committee environments, the particular political context of committees, and also hesitation over whether MPs might conceptualise committee chair roles given that their primary leadership touchstones will be those at the top of their own parliamentary parties.

\section{Conclusions: Parliamentary Committee Leadership in Perspective}

House of Commons select committee chairs are increasingly important actors in the successful delivery of parliamentary scrutiny of the executive. They are pivotal in enabling committees to function effectively, and in facilitating an environment where collegiate working can result in consensus report production in the context of a broader institutional setting where adversarial parliamentary politics are the defining feature of the party battle. In exploring the leadership dynamics of the select committee chair role, this article advances both our conceptualisations of these particular political actors and our understanding of the everyday leadership practices they deploy. The collaborative leadership frame and the chair interviews together illustrate just how complex the chair role is, as evidenced by the range of leadership tools and resources which chairs develop and deploy in order to manage that complexity. The interviews also provide compelling empirical evidence of the tensions inherent in leadershipfollowership dynamics in contemporary political contexts. Some concluding remarks usefully illuminate the landscape for future research.

First, the shift inside the House of Commons towards elected select committee chairs has facilitated their emergence as significant and resourceful parliamentary actors. With their connective tissue to the party business managers largely severed, at least as far as their institutional positioning is concerned, chairs evidently now utilise their democratic legitimacy not just as a scrutiny tool, but also as a leadership resource. They are empowered in ways they never were before, and this makes the analysis of their roles all the richer. There is valuable work to be done in analysing how this role continues to change in the future.

Second, chairs are ultimately responsible for making their committees function as effective scrutiny vehicles. This means they must foster collegiality amongst MPs who naturally bring different party perspectives to bear on committee policy inquiries, and may be serving on the committee for many different reasons, not all of which will involve notions of advancing the public good through parliamentary scrutiny. That committees comprise elite politicians with different views on the committee's rightful focus (in terms of policy orientation, evidence base, approach to ministerial questioning, etc.) and also with different motivations for involvement (political advancement, policy advocacy, backbench 'make-work', etc.), consequently involves chairs exhibiting a range of leadership skills and strategies in order to advance committee goals. Exploring how chairs perform these tasks and successfully (or unsuccessfully) deliver useful scrutiny outputs provides a compelling insight into how actors operate in complex institutional contexts where actors possess competing loyalties. Crucially, it also affords an insight into how those actors behave as leaders in an environment where all MPs on a committee are already members of the political elite, and already acknowledge political (party) leadership through other channels.

Third, this work maps new terrain by analysing parliament from a fresh perspective. While questions about internal organization and processes, legislative management, scrutiny and oversight capacity, executive-legislative relations, and so on, are all obviously important avenues for exploration, this article provides a new lens on their analysis by employing ideas about political leadership in the parliamentary context. Applying this perspective to the role of select committee chair, a crucially positioned institutional actor, not only helps us better understand how these committees are organized and function, but also begins the process of mapping what it means to be a parliamentary political leader outside the framework of parliamentary party leadership. Conceiving of select committee chairs as political leaders inside parliament can thus reposition our understanding of chairs while also providing empirical insights that enrich our academic perspectives on contemporary political leadership. In particular, the specific features of select committee membership afford opportunities to explore the contested and controversial idea of followership, which the interview evidence presented here demonstrates is a slippery concept when applied to political elites in these parliamentary committee contexts.

Finally, the article shows that leadership analyses can go beyond studies of presidents, prime ministers, 
and party leaders, in order to examine more lowly political figures who may not automatically spring to mind in the context of political leadership, but who are nonetheless performing important leadership roles in a system of dispersed democratic governance. Future development of these concepts and ideas can therefore expand our understanding of what political leadership is and does, the diverse institutional contexts in which we find it, and how actors themselves understand leadership and practice it in their everyday political life.

\section{Acknowledgements}

The research for this article was funded by the Economic and Social Research Council (ESRC), grant reference RES-061-25-0391.

\section{Conflict of Interests}

The author declares no conflict of interests.

\section{References}

Alvesson, M. (2011). Leadership and organizational culture. In A. Bryman, D. Collinson, K. Grint, B. Jackson, \& M. Uhl-Bien (Eds.), The Sage handbook of leadership. London: Sage.

Ansell, C., \& Gash, A. (2008). Collaborative governance in theory and practice. Journal of Public Administration Research and Theory, 18(4), 543-571.

Baker, S. D. (2007). Followership: The theoretical foundation of a contemporary construct. Journal of Leadership and Organizational Studies, 14(1), 5060.

Bennister, M. (2012). Prime Ministers in power: Political leadership in Britain and Australia. Basingstoke: Palgrave Macmillan.

Blick, A., \& Jones, G. (2014). The contingencies of prime ministerial power in the UK. In R. A. W. Rhodes \& P. 't Hart (Eds.), The Oxford handbook of political leadership. Oxford: Oxford University Press.

Bligh, M. C. (2011). Followership and follower-centred approaches. In A. Bryman, D. Collinson, K. Grint, B. Jackson, \& M. Uhl-Bien (Eds.), The Sage handbook of leadership. London: Sage.

Blondel, J. (2014). What have we learned? In R. A. W. Rhodes \& P. 't Hart (Eds.), The Oxford handbook of political leadership. Oxford: Oxford University Press.

Burns, J. M. (1978). Leadership. New York: Harper Perennial.

Burns, J. M. (2005). Leadership. Leadership, 1(1), 11-12.

Caro, R. A. (2002). Master of the Senate. London: Jonathan Cape.

Carsten, M. K., Uhl-Bein, M., West, B. L., Patera, J. L., \& McGregor, R. (2010). Exploring social constructions of followership: A qualitative study. The Leadership
Quarterly, 21(3), 543-562.

Collinson, D. L. (2005). Dialectics of leadership. Human Relations, 58(11), 1419-1442.

Cooper, J., \& Brady, D. W. (1981). Institutional context and leadership style: The House from Cannon to Rayburn. American Political Science Review, 75(2), 411-425.

Drewry, G. (1985). The 1979 reforms - New labels on old bottles? In G. Drewry (Ed.), The new select committees: A study of the 1979 reforms. Oxford: Clarendon Press.

Foley, M. (2000). The British Presidency: Tony Blair and the politics of public leadership. Manchester: Manchester University Press.

Giddings, P. (1985). What has been achieved? In G. Drewry (Ed.), The new select committees: A study of the 1979 reforms. Oxford: Clarendon Press.

Giddings, P. (1994). Select committees and parliamentary scrutiny: Plus ca change? Parliamentary Affairs, 47(4), 669-686.

Goleman, D. (2013). Focus: The hidden driver of excellence. New York: HarperCollins.

Greenstein, F. I. (1988). Leadership in the modern presidency. Cambridge, MA: Harvard University Press.

Greenstein, F. I. (2009). The presidential difference: Leadership style from FDR to Barack Obama. Princeton: Princeton University Press.

Gronn, P. (2002). Distributed leadership as a unit of analysis. The Leadership Quarterly, 13(4), 423-452.

Hartley, J., \& Benington, J. (2011). Political leadership. In A. Bryman, D. Collinson, K. Grint, B. Jackson, \& M. Uhl-Bien (Eds.), The Sage handbook of leadership. London: Sage.

Heffernan, R. (2005). Exploring (and explaining) the British Prime Minister. British Journal of Politics and International Relations, 7(4), 605-620.

Heifetz, R. A., Grashow, A., \& Linksy, M. (2009). The practice of adaptive leadership. Boston, MA: Harvard Business Press.

Hendriks, F., \& Karsten, N. (2014). Theory of democratic leadership. In R. A. W. Rhodes \& P. 't Hart (Eds.), The Oxford handbook of political leadership. Oxford: Oxford University Press.

Hennessy, P. (2000). The Prime Minister: The office and its holders since 1945. London: Penguin.

Herrnson, P. S. (1998). Directing 535 leading men and leading ladies: Party leadership in the modern Congress. In H. F. Weisberg \& S. C. Patterson (Eds.), Great theatre: The American Congress in the 1990s. Cambridge: Cambridge University Press.

Hindmoor, A., Larkin, P., \& Kennon, A. (2009). Assessing the influence of select committees in the UK: The education and skills committee 1997-2005. Journal of Legislative Studies, 15(1), 71-89.

Jewell, M. E., \& Whicker, M. L. (1994). Legislative leadership in the American States. Ann Arbor: The University of Michigan Press. 
Judge, D. (1992). The 'effectiveness' of the post-1979 select committee system: The verdict of the 1990 procedure Committee. Political Quarterly, 63(1), 91-100.

Judge, D. (1993). The Parliamentary State. London: Sage.

Kane, J., \& Patapan, H. (2012). The democratic leader: How democracy defines, empowers and limits its leaders. Oxford: Oxford University Press.

Kelso, A. (2003). Where were the massed ranks of parliamentary reformers? Attitudinal and contextual approaches to parliamentary reform. Journal of Legislative Studies, 9(1), 57-76.

Kelso, A. (2009a). Parliamentary reform at Westminster. Manchester: Manchester University Press.

Kelso, A. (2009b). Parliament on its knees: MPs' expenses and the crisis of transparency at Westminster. Political Quarterly, 80(3), 329-338.

Kelso, A., Bennister, M. \& Larkin, P. (in press). The shifting landscape of prime ministerial accountability to parliament: An analysis of Liaison Committee scrutiny sessions. British Journal of Politics and International Relations.

Klijn, E. H. (2014). Political leadership in networks. In R. A. W. Rhodes \& P. 't Hart (Eds.) The Oxford handbook of political leadership. Oxford: Oxford University Press.

Kogler-Hill, S. E. (2010). Team leadership. In P. G. Northouse (Ed.), Leadership: Theory and practice. London: Sage.

McKay, D. (2014). Leadership and the American presidency. In R. A. W. Rhodes \& P. 't Hart (Eds.), The Oxford handbook of political leadership. Oxford: Oxford University Press.

Meindl, J. R. (1990). On leadership: An alternative to conventional wisdom. Research in Organizational Behaviour, 12(1), 158-203.

Meindl, J. R. (1995). The romance of leadership as a follower-centric theory: A social constructionist approach. The Leadership Quarterly, 6(3), 329-341.

Neustadt, R. E. (1960). Presidential power: The politics of leadership. New York: Wiley.

Neustadt, R. E. (1980). Presidential power: The politics of leadership from FDR to Carter. New York: Wiley.

Northouse, P. G. (2010). Leadership: Theory and practice (5th ed.). London: Sage.

Norton, P. (2012). Comparing leadership patterns and dynamics in the legislative arena. In L. Helms (Ed.). Comparative political leadership. Basingstoke: Palgrave Macmillan.

Norton, P. (2013). Parliament in British Politics. Basingstoke: Palgrave Macmillan.

Nye, J. S. (2008). The power to lead. Oxford: Oxford University Press.

Peabody, R. L. (1976). Leadership in Congress: Stability, succession and change. Boston: Little, Brown.

Peabody, R. L. (1985). Leadership in legislatures: Evolu- tion, selection and functions. In G. Loewenberg, S. C. Patterson, \& M. E. Jewell (Eds.), Handbook of legislative research. Cambridge, MA: Harvard University Press.

Peters, R. M. (1990). The American speakership. Baltimore: Johns Hopkins University Press.

Rhodes, R. A. W. (1997). Understanding governance. Buckingham: Open University Press.

Rhodes, R. A. W., \& 't Hart, P. (Eds.). (2014a). The Oxford handbook of political leadership. Oxford: Oxford University Press.

Rhodes, R. A. W., \& 't Hart, P. (2014b). Puzzles of political leadership. In R. A. W. Rhodes \& P. 't Hart (Eds.), The Oxford handbook of political leadership. Oxford: Oxford University Press.

Rost, J. (2008). Followership: An outmoded concept. In R. E. Riggio, I. Chaleff, \& J. Lipman-Blumen (Eds.), The art of followership: How great followers create great leaders and organizations. San Francisco: Jossey-Bass.

Ruscio, K. (2004). The leadership dilemma in modern democracies. Cheltenham: Edward Elgar.

Russell, M. (2011). 'Never allow a crisis to go to waste': The Wright committee reforms to strengthen the House of Commons. Parliamentary Affairs, 64(4), 612-633.

Russell, M., \& Benton, M. (2011). Selective influence: The policy impact of House of Commons select committees. London: The Constitution Unit.

Shein, E. H. (1992). Organizational culture and leadership. San Francisco: Jossey-Bass Inc..

Smith, S. S. (2007). Party influence in Congress. In S. S. Smith, J. M. Roberts, \& R. J. Vander Wielen (Eds.), The American Congress reader. New York: Cambridge University Press.

Smith, S. S., \& Deering, C. J. (1984). Committees in Congress. Washington D.C.: Congressional Quarterly.

Strahan, R. W. (2007). Leading representatives: The agency of leaders in the politics of the US House. Baltimore: Johns Hopkins University Press.

Strahan, R. W. (2011). Party leadership. In E. Schickler \& F. E. Lee (Eds.), The Oxford handbook of the American Congress. Oxford: Oxford University Press.

't Hart, P. (2014). Understanding public leadership. London: Palgrave.

Uhl-Bein, M. (2006). Relational leadership theory: Exploring the social processes of leadership and organizing. The Leadership Quarterly, 17(6), 654-676.

Uhl-Bien, M., Marion, R., \& McKelvery, B. (2007). Complexity leadership theory: Shifting leadership from the industrial age to the knowledge era. The Leadership Quarterly, 18(4), 298-318.

Uhr, J., \& Wanna, J. (2000). The future roles of parliament. In M. Keating, J. Wanna, \& P. Weller (Eds.), Institutions on the edge? Capacity for governance. Sydney: Allen \& Unwin. 
Weller, P. (2014). The variability of prime ministers. In R. A. W. Rhodes \& P. 't Hart (Eds.) The Oxford hand- book of political leadership. Oxford: Oxford University Press.

\section{About the Author}

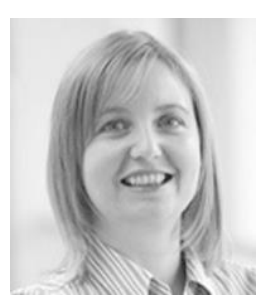

Alexandra Kelso is Associate Professor of Politics at the University of Southampton. Her research encompasses UK parliamentary politics, democracy and public engagement, political leadership, and public policy. She has won funding for her research from the ESRC and the Nuffield Foundation. In 2016, she became Associate Fellow at the Crick Centre, University of Sheffield, and Executive Board member on the Designing For Democracy Programme. 